\title{
The effect of the Falcon 460 EC fungicide on soil microbial communities, enzyme activities and plant growth
}

\author{
Małgorzata Baćmaga $^{1} \cdot$ Jadwiga Wyszkowska $^{1} \cdot$ Jan Kucharski $^{1}$
}

Accepted: 16 August 2016 / Published online: 8 September 2016

(C) Springer Science+Business Media New York 2016

\begin{abstract}
Fungicides are considered to be effective crop protection chemicals in modern agriculture. However, they can also exert toxic effects on non-target organisms, including soil-dwelling microbes. Therefore, the environmental fate of fungicides has to be closely monitored. The aim of this study was to evaluate the influence of the Falcon 460 EC fungicide on microbial diversity, enzyme activity and resistance, and plant growth. Samples of sandy loam with $\mathrm{pH}_{\mathrm{KCl}} 7.0$ were collected for laboratory analyses on experimental days 30, 60 and 90. Falcon 460 EC was applied to soil in the following doses: control (soil without the fungicide), dose recommended by the manufacturer, 30 -fold higher than the recommended dose, 150 -fold higher than the recommended dose and 300-fold higher than the recommended dose. The observed differences in the values of the colony development index and the eco-physiological index indicate that the mixture of spiroxamine, tebuconazole and triadimenol modified the biological diversity of the analyzed groups of soil microorganisms. Bacteria of the genus Bacillus and fungi of the genera Penicillium and Rhizopus were isolated from fungicide-contaminated soil. The tested fungicide inhibited the activity of dehydrogenases, catalase, urease, acid phosphatase and alkaline phosphatase. The greatest changes were induced by the highest fungicide dose 300-fold higher than the
\end{abstract}

Jadwiga Wyszkowska

jadwiga.wyszkowska@uwm.edu.pl

Małgorzata Baćmaga

m.bacmaga@uwm.edu.pl

Jan Kucharski

jan.kucharski@uwm.edu.pl

1 Department of Microbiology, University of Warmia and Mazury in Olsztyn, Plac Łódzki 3, Olsztyn 10-727, Poland recommended dose. Dehydrogenases were most resistant to soil contamination. The Phytotoxkit test revealed that the analyzed fungicide inhibits seed germination capacity and root elongation. The results of this study indicate that excessive doses of the Falcon 460 EC fungicide 30-fold higher than the recommended dose to 300 -fold higher than the recommended dose) can induce changes in the biological activity of soil. The analyzed microbiological and biochemical parameters are reliable indicators of the fungicide's toxic effects on soil quality.

Keywords Fungicides · Soil microorganisms · Soil enzymes · Soil resistance $\cdot$ Phytotoxkit test

\section{Introduction}

The quality of life is inextricably linked with environmental health. This balance can be disturbed by biosphere contamination with fungicides which pose a serious problem for food safety and sustainable soil use. Fungicide are chemical substances that are most widely used to combat fungal diseases in production systems. They directly influence basic life processes in fungi, including respiration, sterol biosynthesis and cell division (Seiber and Kleinschmidt 2011). Most fungal diseases in plants are difficult to treat, which is why fungicides can be applied several times during the growing season or even across several seasons. Frequent fungicide use can pose a threat to the natural environment, mainly soil, by promoting the accumulation and migration of toxic substances in ecosystems. Fungicides exert a negative effect on soil-dwelling microorganisms and biochemical processes in soil (Wyszkowska and Kucharski 2004; Banks et al. 2005; Chatterjee et al. 2013; Wightwick et al. 2013). Their influence on the environment has to be continuously 
monitored to guarantee soil ecosystem homeostasis. The risks associated with fungicide use can be controlled by analyzing the biological activity of soil. Microorganisms and enzymes, which are sensitive to stress and respond to contamination faster than other parameters, are potential indicators of soil quality (Singh and Kumar 2008; Truu et al. 2008; Tejada 2009). They participate in various soil processes, including organic matter transformation, nutrient release and decomposition of chemical compounds. Microorganisms and enzymes play a key role in the functioning of many ecosystems (Tejada et al. 2011). The adverse effects of fungicides on soil health can be manifested by changes in the size and biodiversity of microbial populations and inhibited activity of soil enzymes (Ratcliff et al. 2006; Baćmaga et al. 2012; Zhang et al. 2014). Fungicides can be degraded in soil by hydrolysis, evaporation, oxidation, photolysis, ionization and microbiological decomposition. Microorganisms are most effective in transforming harmful chemical substances in the soil ecosystem (Katayama et al. 2010). The rate at which fungicides are degraded is determined mainly by their chemical structure and persistence (Arias-Estéves et al. 2008). Not all fungicides have toxic effects on soil-dwelling microorganisms. Some microbial species and strains become tolerant to chemical substances by developing defense mechanisms (Katayama et al. 2010; Komárek et al. 2010).

Fungicides can also exert toxic effects on non-target organisms, and this observation spurred significant interest in their effects on soil microorganisms (Guo et al. 2015). Despite the environmental risks associated with fungicide use, those chemicals continue to offer effective protection for crops, and they cannot be entirely eliminated. For this reason, the impact of fungicides on non-target organisms and the risks resulting from exposure to fungicides have to be thoroughly investigated (Chen et al. 2011; Jezierska-Tys and Rutkowska 2013). Soil microorganisms and enzymes can be used to model the harmful influence of pesticides on soil ecosystems. Those indicators can also be used in the process of soil detoxification (Maltby et al. 2009).

Falcon 460 EC is a crop fungicide that contains three active ingredients: spiroxamine, tebuconazole and triadimenol. Spiroxamine [8-tert-butyl-1,4-dioxaspiro[4.5]decan2-ylmethyl(ethyl)(propyl)amine] is a ketoamine group compound which protects cereals against powdery mildew. Spiroxamine inhibits sterol biosynthesis, and its half-life in soil ranges from 37 to 44 days (Sukul et al. 2010). Tebuconazole [1-(4-chlorophenyl)-4,4-dimethyl-3-(1H, 1,2,4-triazol-1-ylmethyl)pentan-3-ol] is a triazole group compound which protects cereals against fungal diseases by inhibiting sterol biosynthesis and disrupting membrane function (Ahemad and Khan 2011). It has a half-life of 49-610 days in soil (Muñoz-Leoz et al. 2011). Triadimenol [1-(4-chlorophenoxy)-3,3-dimethyl-1-(1,2,4-triazol-1-yl)butan2-ol] is also a triazole, and it is used mainly to fight powdery mildew in cereals and vegetables (Dong et al. 2010). It has a half-life of 30-50 days in the soil environment (Garrison et al. 2011).

The aim of this study was to evaluate the effects of spiroxamine, tebuconazole and triadimenol, the active ingredients of the Falcon 460 EC fungicide, on the biological activity of soil which has not been fully elucidated. Various analyses were carried out to determine fungicide doses that strongly influence soil-dwelling microorganisms and biological processes in soil. The values of microbiological and biochemical indicators were calculated and the fungicide's toxic effects on Lepidium sativum, Sinapis alba and Sorghum saccharatum plants were determined to evaluate the environmental risks associated with improper use of the tested product. The applied biological tests are suitable for monitoring the condition of soil exposed to pesticides.

\section{Materials and Methods}

\section{Soil}

The model experiment was carried out on sandy loam (sand $-69.41 \%$, silt-27.71\%, clay-2.88\%), classified as Eutric Cambisols according to the World Reference Base of Soil Resources (2014). Soil samples were characterized by the following parameters: $\mathrm{pH}$ in $1 \mathrm{Mol} \mathrm{KCl} \mathrm{dm}-3.0$, hydrolytic acidity (HAC) $-6.4 \mathrm{mMol}^{(+)} \mathrm{kg}^{-1}$, total exchangeable bases (TEB) - $165.9 \mathrm{mMol}^{(+)} \mathrm{kg}^{-1}$, organic carbon content $\left(\mathrm{C}_{\mathrm{org}}\right)-14.30 \mathrm{~g} \mathrm{~kg}^{-1}$, total nitrogen content $\left(N_{\text {total }}\right)-0.98 \mathrm{~g} \mathrm{~kg}^{-1}$, total exchangeable cations in $\mathrm{m} \mathrm{kg}^{-1}$ : $\mathrm{K}^{+}-186, \mathrm{Ca}^{2+}-2571.4, \mathrm{Na}^{+}-20.0, \mathrm{Mg}^{2+}$-59.5. Soil samples were collected from the arable layer (depth of 0-20 $\mathrm{cm}$ ) in the Agricultural Experiment Station in Tomaszkowo (north-eastern Poland, 53.71610N, 20.41670E). The physicochemical properties of soil were determined with the use of the following methods: granulometric compositionMastersizer 2000 laser diffraction particle size analyzer, $\mathrm{pH}$ - potentiometrically in $1 \mathrm{Mol} \mathrm{KCl} \mathrm{dm}{ }^{-3}$, hydrolytic acidity and total exchangeable bases-by the method described by Kappen (Carter 1993), organic carbon content—by the method proposed by Tiurin, total nitrogen content-by Kjeldahl's method (Nelson and Sommers 1996), and the content of exchangeable $\mathrm{K}^{+}, \mathrm{Na}^{+}, \mathrm{Ca}^{2+}, \mathrm{Mg}^{2+}$ cations-by flame photometry (Harris 2006).

\section{Fungicide}

The Falcon 460 EC fungicide, which contains three active ingredients spiroxamine $\left(250 \mathrm{~g} \mathrm{dm}^{-3}\right)$, tebuconazole 
$\left(167 \mathrm{~g} \mathrm{dm}^{-3}\right)$ and triadimenol $\left(43 \mathrm{~g} \mathrm{dm}^{-3}\right)$, was analyzed. The tested fungicide is manufactured by Bayer CropScience, and it was introduced to the Polish market in 2009. The dose recommended by the manufacturer is 0.6 $\mathrm{dm}^{3} \mathrm{ha}^{-1}$, which corresponds to $0.092 \mathrm{mg} \mathrm{kg}^{-1} \mathrm{DM}$ of soil on an active ingredient basis. Falcon $460 \mathrm{EC}$ was applied to soil in the following doses: control (soil without the fungicide), RD (dose recommended by the manufacturer), 30fold higher than the recommended dose $(30 \times \mathrm{RD}), 150$-fold higher than the recommended dose $(150 \times \mathrm{RD})$ and 300 -fold higher than the recommended dose $(300 \times \mathrm{RD})$. Soil was contaminated with doses several times higher than the recommended dose of Falcon 460 EC to investigate the outcomes of accidental overexposure to the fungicide due to inappropriate use.

\section{Experimental design}

Glass beakers with the volume of $150 \mathrm{~cm}^{3}$ were filled with $100 \mathrm{~g}$ samples of air-dry soil passed through a $2 \mathrm{~mm}$ sieve. A water emulsion of the tested fungicide was applied to beakers in the following doses: control (soil without the fungicide), RD (dose recommended by the manufacturer), $30 \times \mathrm{RD}, 150 \times \mathrm{RD}$ and $300 \times \mathrm{RD}$, in three biological replications. On experimental days 30, 60 and 90, separate sets of beakers filled with soil were used to obtain a total of 45 treatments (five fungicide doses $\times 3$ dates of analysis $\times 3$ replications). Soil was mixed with the fungicide and brought to $50 \%$ capillary water capacity with the use of deionized water. It was covered with perforated film and incubated at a temperature of $25{ }^{\circ} \mathrm{C}$ for 90 days. Soil moisture content was monitored and kept constant throughout the experiment. On experimental days 30, 60 and 90, soil samples were collected for microbiological and enzymatic analyses and the Phytotoxkit test. The Phytotoxkit test was carried out in three replications. Ten seeds of Lepidium sativum, Sinapis alba and Sorghum saccharatum were used per replication. The experimental conditions and procedure were identical to those used in microbiological and enzymatic analyses.

\section{Soil-dwelling microorganisms}

On experimental days 30,60 and 90, serial dilutions of soil samples were subjected to microbiological analyses. Soil samples $(10 \mathrm{~g})$ were combined with sterile saline solution $\left(90 \mathrm{~cm}^{3} 0.85 \% \mathrm{NaCl}\right)$ and shaken for $30 \mathrm{~min}$ at $120 \mathrm{rpm}$. Diluted soil samples (organotrophic bacteria and actinomycetes $-10^{-5}$, fungi $-10^{-3}$ ) were placed on Petri dishes, and selective culture media were added. Microbiological analyses of soil from each beaker, including control soil without the fungicide and soil contaminated with Falcon 460 EC (three beakers per fungicide dose), were performed in three technical replications (a total of nine observations for each dose). Organotrophic bacteria were cultured on Bunt and Rovira's medium with the addition of the soil extract (Alexander 1973), actinomycetes were cultured on Küster and Williams' medium with the addition of antibiotics nystatin and actidione (Parkinson et al. 1971), and fungi were cultured on Martin's medium (1950) with the addition of rose bengal and antibiotic aureomycin. The prepared specimens were incubated at a constant temperature of $28^{\circ} \mathrm{C}$. Microbial colonies were counted every day with a colony counter, and the colony development index (CD) was determined as $\mathrm{CD}=\left[N_{1} / 1+N_{2} / 2+\mathrm{N}_{3} / 3 \ldots N_{10} /\right.$ 10] $\times 100$, where $N_{1}, N_{2}, N_{3}, \ldots N_{10}$ denotes the number of colonies after $1,2,3 \ldots 10$ days of incubation (Sarathchandra et al. 1997). The eco-physiological (EP) index was calculated as $\mathrm{EP}=-\sum$ (pi $\left.\log \mathrm{pi}\right)$, where pi denotes the number of microbial colonies on a given day divided by the total number of colonies (De Leij et al. 1993).

On day 90, microorganisms were isolated from control samples and experimental soil samples contaminated with the Falcon 460 EC fungicide (RD and $300 \times \mathrm{RD}$ ). Serial dilutions were prepared by suspending $10 \mathrm{~g}$ of soil from each sample in sterile saline solution at a ratio of 1:10. Every dilution in the amount of $1 \mathrm{~cm}^{3}$ (bacteria- $10^{-5}$, fungi- $10^{-3}$ ) was placed on Petri dishes in three replications. Microorganisms were isolated with the use of the following culture media: PCA for determining total bacterial counts, and Sabouraud dextrose agar with chloramphenicol agar for yeasts. The prepared specimens were incubated under aerobic conditions at a temperature of $37^{\circ}$ $\mathrm{C}$ for $24-48 \mathrm{~h}$. Serial passages of characteristic colonies of the isolated microorganisms were performed to obtain pure cultures. Genomic DNA was isolated with the Bead-Beat Micro Gravity kit (A\&A Biotechnology, Poland). The isolated genomic DNA was separated by electrophoresis in $1 \%$ agarose gel $\left(5 \mathrm{~mm}^{3}\right.$ samples on gel). The PCR reaction volume was $50 \mathrm{~mm}^{3}$, and the reaction mixture had the following composition: $5 \mathrm{~mm}^{3}(\sim 50 \mathrm{ng})$ genomic DNA from the sample, $25 \mathrm{~mm}^{3} 2 \mathrm{x}$ PCR Master Mix Plus High GC (A\&A Biotechnology), $0.2 \mathrm{~mm}^{3}$ of each primer with the concentration of $100 \mu \mathrm{M}$, and $19.6 \mathrm{~mm}^{3}$ of sterile water. The sequence of the bacterial 16S rRNA gene was amplified with the following primer pair: B-all Forward GAG TTT GAT CCT GGC TCA G and B-all Reverse ACG GCT ACC TTA CGA CTT. The isolated bacterial DNA was subjected to PCR with the following thermal cycling profile: initial denaturation $\left(94^{\circ} \mathrm{C}\right.$ for $2 \mathrm{~min}, 1$ cycle), denaturation $\left(94{ }^{\circ} \mathrm{C}\right.$ for $30 \mathrm{~min}, 30$ cycles $)$, primer annealing $\left(58^{\circ} \mathrm{C}\right.$ for $45 \mathrm{~s}, 30$ cycles), elongation $\left(72^{\circ} \mathrm{C}\right.$ for $80 \mathrm{~s}$, 30 cycles $)$, final elongation $\left(72^{\circ} \mathrm{C}\right.$ for $5 \mathrm{~min}, 1$ cycle $)$. The fungal ITS region was amplified with the following primers: ITS1: TTC GTA GGT GAA CCT GCG G and ITS4: TCC 
TCC GCT TAT TGA TAT GC. The isolated fungal DNA was subjected to PCR with the following thermal cycling profile: initial denaturation $\left(94^{\circ} \mathrm{C}\right.$ for $2 \mathrm{~min}, 1$ cycle), denaturation $\left(94^{\circ} \mathrm{C}\right.$ for $30 \mathrm{~min}, 30$ cycles $)$, primer annealing $\left(54{ }^{\circ} \mathrm{C}\right.$ for $45 \mathrm{~s}, 30$ cycles), elongation $\left(72{ }^{\circ} \mathrm{C}\right.$ for $1 \mathrm{~min}$, 30 cycles), final elongation $\left(72^{\circ} \mathrm{C}\right.$ for $5 \mathrm{~min}, 1$ cycle). After PCR, the reaction mixture was separated on $2 \%$ agarose gel $\left(2 \mathrm{~mm}^{3}\right.$ samples on gel). Amplified DNA fragments were purified with the Clean-Up AX kit (A\&A Biotechnology, Poland). PCR products were suspended in $10 \mathrm{mM}$ Tris- $\mathrm{HCl}$ $\mathrm{pH} 8.0$, diluted to a concentration of $100 \mathrm{ng} \mathrm{mm}^{-3}$. DNA was sequenced by Macrogen (Netherlands). The resulting DNA sequences were compared with GenBank (National Center of Biotechnology Information) data with the use of the Basic Local Alignment Search Tool (BLAST) software. Nucleotide sequences of the isolated microorganisms were used to develop a phylogenetic tree by the neighbor-joining method in the MEGA 7.0 program.

\section{Soil enzymes}

Soil enzymatic activity was determined on experimental days 30, 60 and 90 in six replications. Enzymatic analyses of soil from each beaker, including control soil without the fungicide and soil contaminated with Falcon 460 EC (three beakers per fungicide dose), were performed in two technical replications (a total of six observations for each dose). The activity of the following enzymes was analyzed: dehydrogenases according to the method described by Öhlinger (1996), catalase and urease according to the method proposed by Alef and Nannipieri (1998), acid phosphatase and alkaline phosphatase according to the method described by Alef et al. (1998). The activity of the tested enzymes was determined with the use of the following substrates: 2,3,5-triphenyltetrazolium chloride (Stanlab, Poland) for dehydrogenases, $\mathrm{H}_{2} \mathrm{O}_{2}$ (Stanlab, Poland) for catalase, urea (Eurochem BGD, Poland) for urease, 4-nitrophenyl phosphate disodium (ApliChem, Germany) for acid phosphatase and alkaline phosphatase. The activity of the analyzed soil enzymes, excluding catalase, was measured with the Perkin-Elmer Lambda 25 spectrophotometer (Massachusetts, USA) at the wavelength of $485 \mathrm{~nm}$ for dehydrogenases, and $410 \mathrm{~nm}$ for urease, acid phosphatase and alkaline phosphatase. Catalase activity was determined in a reaction between hydrogen peroxide and potassium permanganate. Enzyme activity was expressed in the following units per $1 \mathrm{~kg}^{-1} \mathrm{DM} \mathrm{h}^{-1}$ soil: dehydrogenases

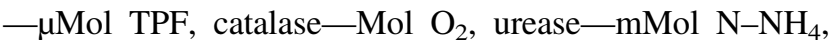
acid phosphatase and alkaline phosphatase-mMol PNP.

The results of enzyme activity tests (dehydrogenases, catalase, urease, acid phosphatase and alkaline phosphatase) in soil samples contaminated with the Falcon 460 EC fungicide were used to determine soil resistance (RS) on day 30 based on the formula proposed by Orwin and Wardle (2004).

$R S\left(t_{0}\right)=1-\frac{2\left|D_{o}\right|}{\left(\left|C_{o}\right|+\left|D_{o}\right|\right)}$

where $C_{0}$ is the soil resistance under natural conditions over time $t_{0}$, and $P_{0}$ is the resistance of soil subjected to pressure over time $t_{0}, D_{0}=C_{0}-P_{0}$

\section{Fungicide phytotoxicity}

The influence of the mixture of spiroxamine, tebuconazole and triadimenol on plants grown from the seeds of Lepidium sativum, Sinapis alba and Sorghum saccharatum was determined with the Phytotoxkit test. On experimental days 30,60 and $90,110 \mathrm{~g}$ of control soil with the addition of the tested fungicide $(\mathrm{RD}, 30 \times \mathrm{RD}, 150 \times \mathrm{RD}, 300 \times \mathrm{RD})$ were placed on plastic plates. Ten seeds of every analyzed plant were placed on filter paper in three dishes (three replications). They were incubated in vertical position at a temperature of $25^{\circ} \mathrm{C}$ for $72 \mathrm{~h}$. After incubation, the percentage of inhibited seed germination (ISG) and inhibited root growth (IRG) was calculated according to the below formula (Lipińska et al. 2015):

$I S G(I R G)=\frac{(A-B)}{A} \cdot 100$

where ISG is the percentage of inhibited seed germination, IRG the percentage of inhibited root growth, $A$ the seed germination or root growth in the control sample (without the fungicide), $B$ seed germination or root growth in experimental samples (with fungicide).

\section{Statistical analysis}

The results were processed in the Statistica 12.5 program (StatSoft, Inc. 2015). The percentage of observed variance was determined by computing $\eta^{2}$ values in ANOVA $(p=$ 0.01). The effects of experimental factors (fungicide dose and soil incubation time) on microbial diversity, enzyme activity and plant growth were compared in two-way repeated measures ANOVA. Fungicide dose was the between-subjects factor, and soil incubation time was the repeated measures factor. Homogeneous groups were determined by one-way and two-way ANOVA with Tukey's range test at a significance level of $p=0.01$. The activity of soil enzymes was determined by principle component analysis (PCA) with multidimensional and exploratory data analyses. The strength of the relationships between fungicide dose vs. enzyme resistance, $\mathrm{CD}$ index, EP index and ISG (IRG) values was determined by calculating linear correlation coefficients. 


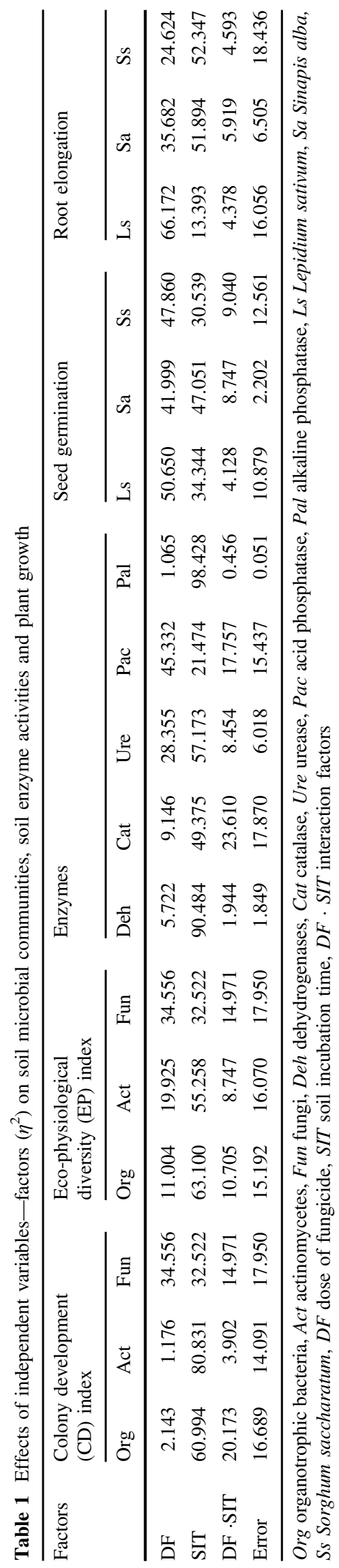

\section{Results and discussion}

\section{Soil-dwelling microorganisms}

The widespread use of pesticides not only leads to changes in microbial counts and their metabolic activity, but it can also modify microbial biodiversity (Ratcliff et al. 2006; Cycoń et al. 2011; Baćmaga et al. 2015c). According to Wang et al. (2006) and Widenfalk et al. (2008), pesticides can induce physiological and biochemical changes in soildwelling microorganisms, thus influencing their biodiversity. Some pesticides can inhibit or even eliminate microbial groups, whereas others act as growth stimulators for selected populations of soil microorganisms. Those changes can be attributed to microorganisms' ability to degrade crop protection products or modify the structure of microbial communities. One of the key determinants of pesticides' effects on soil-dwelling microbes is their bioavailability. Pesticide concentrations in the soil solution are regulated by adsorption and desorption (Demenaou et al. 2004). Menon et al. (2005) analyzed the effects of chlorpyrifos and quinalphos on microbial diversity in loamy sand and sandy loam and observed that both products had more a more toxic influence on microorganisms in loamy sand than in sandy loam. They attributed their findings to the tested products' higher availability in loamy sand which is less abundant in clay and organic carbon. In this study, microbial diversity in the analyzed soil samples was determined by calculating the colony development (CD) index and the eco-physiological diversity (EP) index. Both indices supply information about changes in the proportions of slowgrowing (K-strategists) and fast-growing (r-strategists) microorganisms. Genetic differences between microorganisms support adaptation to environmental changes and survival (De Leij et al. 1993). The proliferation of microbial colonies on each day of the experiment was monitored based on the values of the $\mathrm{CD}$ index which ranges from 0 to 100. Values close to 100 point to rapid growth of microbial populations over a short period of time. A statistical analysis of the observed variance $\left(\eta^{2}\right)$ revealed that soil incubation time had the greatest effect on the CD index (organotrophic bacteria $-60.99 \%$, actinomycetes- $55.26 \%$, fungi- $14.97 \%$ ). The $\mathrm{CD}$ index was affected by fungicide dose to a lesser extent (Table 1). The effect exerted by fungicide dose was statistically significant (Table 2). Average CD values were higher in treatments with the highest fungicide dose $(300 \times \mathrm{RD})$ than in control samples (organotrophic bacteria-by 5.733 , actinomycetes-by 3.885 , fungi-by 0.170 ). The fungicide dose $\times$ soil incubation time interaction was significant, which implies that $\mathrm{CD}$ values changed over time in response to the applied fungicide dose. The fungicide dose of $300 \times \mathrm{RD}$ increased $\mathrm{CD}$ values (Table 3). The highest $(29.12 \%)$ increase in $\mathrm{CD}$ values of organotrophic bacteria 
relative to control was noted on day 60 , whereas an inverse relationship

was observed in fungi. The greatest drop in $C D$ values (from 33.698 to 24.606) was observed on day 90. The same dose did not provoke changes in the $\mathrm{CD}$ values of actinobacteria which remained fairly constant. Regardless of fungicide dose, organotrophic bacteria and actinomycetes were characterized by the highest average $\mathrm{CD}$ values on day 90 , and fungi-on day 30 . The most rapidly proliferating microorganisms were organotrophic bacteria (average CD value of 59.767), whereas the slowest growing microbes were fungi (average CD value of 28.160). Baćmaga et al. (2015b) observed similar correlations, with the exception of actinomycetes, in an analysis of azoxystrobin. The CD values of the evaluated microorganisms increased in response to the highest azoxystrobin dose $\left(22.50 \mathrm{mg} \mathrm{kg}^{-1}\right)$. In a study by Kucharski et al. (2016), the CD values of organotrophic bacteria, actinomycetes and fungi increased relative to control in soil samples exposed to the Boreal 58 WG herbicide. In contrast, the Successor T 550 SC herbicide analyzed by Tomkiel et al. (2014) had a minor effect on the $\mathrm{CD}$ values of soil-dwelling microorganisms.

The biodiversity of soil microorganisms is also related to the EP index. The index takes on values between 0 and 1 , and it measures the stability and uniformity of microbial growth over time. Values closer to 1 point to steady microbial growth in a given environment (De Leij et al. 1993). The percentage of observed variance ranged from 11.00 to $34.56 \%$ for fungicide dose, and from 32.52 to $63.10 \%$ for soil incubation time (Table 1). The results of ANOVA show that fungicide dose and soil incubation time significantly affected the EP index, similarly to the CD index (Table 2). The interaction between the experimental factors was significant for all analyzed microbial groups. EP values were lowest in soil sampled exposed to the fungicide dose of $300 \times \mathrm{RD}$ (Table 4). Relative to control, the above dose decreased the EP values of organotrophic bacteria from 0.620 to 0.585 , actinomycetes-from 0.644 to 0.590 , and fungi-from 0.681 to 0.568 , on average. Organotrophic bacteria, actinomycetes and fungi were characterized by the highest average values on day 60 at $0.671,0.794$ and 0.683 , respectively. Baćmaga et al. (2015a) observed that pesticides can influence the biodiversity of soil-dwelling microorganisms by modifying their EP values. The authors demonstrated that exposure to the mixture of diflufenican, metsulfuron-methyl and iodosulfuron-methyl-sodium increased the EP values of organotrophic bacteria and decreased the EP values of fungi. Tomkiel et al. (2015) reported that the Aurora 40 WG herbicide applied in doses of 0.264 to $42.240 \mathrm{\mu g} \mathrm{kg}^{-1}$ caused the greatest drop in the EP values of fungi.

Microorganisms characterized by high metabolic and enzymatic activity play a very important role in pesticide 
Table 3 Colony development (CD) index in soil contaminated with the Falcon 460 EC fungicide

\begin{tabular}{|c|c|c|c|c|c|c|c|c|c|}
\hline \multirow[t]{3}{*}{ Dose $\mathrm{S}+\mathrm{Te}+\mathrm{Tr}$} & \multicolumn{3}{|c|}{ Organotrophic bacteria } & \multicolumn{3}{|c|}{ Actinomycetes } & \multicolumn{3}{|l|}{ Fungi } \\
\hline & \multicolumn{9}{|c|}{ Soil incubation time, days } \\
\hline & 30 & 60 & 90 & 30 & 60 & 90 & 30 & 60 & 90 \\
\hline Control & $56.609^{\mathrm{a}}$ & $42.035^{\mathrm{b}}$ & $74.221^{\mathrm{c}}$ & $35.255^{\mathrm{c}}$ & $29.931^{\mathrm{a}}$ & $37.030^{\mathrm{c}}$ & $33.603^{\mathrm{c}}$ & $24.051^{\mathrm{d}}$ & $33.698^{\mathrm{c}}$ \\
\hline $\mathrm{RD}$ & $61.240^{\mathrm{a}}$ & $45.355^{\mathrm{b}}$ & $70.080^{\mathrm{c}}$ & $34.686^{\mathrm{c}}$ & $29.925^{\mathrm{a}}$ & $37.012^{\mathrm{c}}$ & $31.967^{\mathrm{c}}$ & $31.783^{c}$ & $26.847^{\mathrm{a}}$ \\
\hline $30 \times \mathrm{RD}$ & $62.011^{\mathrm{a}}$ & $45.384^{\mathrm{b}}$ & $65.656^{\mathrm{a}}$ & $36.319^{c}$ & $29.841^{\mathrm{a}}$ & $35.951^{\mathrm{c}}$ & $27.420^{\mathrm{a}}$ & $31.201^{\mathrm{c}}$ & $26.473^{\mathrm{a}}$ \\
\hline $150 \times \mathrm{RD}$ & $67.085^{\mathrm{c}}$ & $47.522^{b}$ & $69.237^{\mathrm{c}}$ & $37.220^{\mathrm{c}}$ & $30.989^{\mathrm{a}}$ & $37.890^{\mathrm{c}}$ & $25.288^{\mathrm{a}, \mathrm{d}}$ & $29.480^{\mathrm{c}, \mathrm{a}}$ & $26.330^{\mathrm{a}}$ \\
\hline \multirow[t]{2}{*}{$300 \times \mathrm{RD}$} & $65.090^{\mathrm{a}}$ & $54.277^{\mathrm{d}}$ & $70.699^{c}$ & $38.190^{\mathrm{c}}$ & $31.027^{\mathrm{a}}$ & $38.410^{\mathrm{c}}$ & $25.199^{\mathrm{a}, \mathrm{d}}$ & $24.453^{\mathrm{d}}$ & $24.606^{\mathrm{a}, \mathrm{c}}$ \\
\hline & 62.407 & 46.915 & 69.979 & 36.334 & 30.343 & 37.259 & 28.695 & 28.194 & 27.591 \\
\hline$* r$ & $0.725^{*}$ & $0.952 *$ & -0.017 & $0.933 *$ & $0.914 *$ & $0.823 *$ & $0.823 *$ & $-0.432 *$ & $-0.614^{*}$ \\
\hline
\end{tabular}

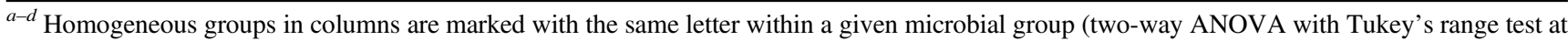
a significance level of $p=0.01$. The between-subjects factor was fungicide dose, and the repeated measures factor was soil incubation time)

$S$ spiroxamine, $T e$ tebuconazole, $T r$ triadimenol; dose of fungicide: control (soil without fungicide), $R D$ dose recommended by the manufacturer, $30 \times R D 30$-fold higher than the recommended dose, $150 \times R D 150$-fold higher than the recommended dose, $300 \times R D 300$-fold higher than the recommended dose, average

* $r$ correlation coefficient significant at $p=0.01, n=3$

Table 4 Eco-physiological diversity (EP) index of microorganisms in soil contaminated with the Falcon 460 EC fungicide

\begin{tabular}{|c|c|c|c|c|c|c|c|c|c|}
\hline \multirow[t]{3}{*}{ Dose $\mathrm{S}+\mathrm{Te}+\mathrm{Tr}$} & \multicolumn{3}{|c|}{ Organotrophic bacteria } & \multicolumn{3}{|c|}{ Actinomycetes } & \multicolumn{3}{|l|}{ Fungi } \\
\hline & \multicolumn{9}{|c|}{ Soil incubation time, days } \\
\hline & 30 & 60 & 90 & 30 & 60 & 90 & 30 & 60 & 90 \\
\hline Control & $0.658^{\mathrm{ab}}$ & $0.715^{\mathrm{a}}$ & $0.486^{\mathrm{c}}$ & $0.729^{\mathrm{b}}$ & $0.828^{\mathrm{a}}$ & $0.650^{\mathrm{d}}$ & $0.619^{\mathrm{b}}$ & $0.840^{\mathrm{a}}$ & $0.637^{\mathrm{b}}$ \\
\hline $\mathrm{RD}$ & $0.614^{\mathrm{b}}$ & $0.711^{\mathrm{a}}$ & $0.565^{\mathrm{d}}$ & $0.703^{\mathrm{b}}$ & $0.824^{\mathrm{a}}$ & $0.656^{\mathrm{d}}$ & $0.626^{\mathrm{b}}$ & $0.667^{\mathrm{c}}$ & $0.619^{\mathrm{b}}$ \\
\hline $30 \times \mathrm{RD}$ & $0.649^{\mathrm{b}}$ & $0.657^{\mathrm{ab}}$ & $0.563^{\mathrm{d}}$ & $0.653^{\mathrm{d}}$ & $0.818^{\mathrm{a}}$ & $0.670^{\mathrm{d}}$ & $0.628^{\mathrm{b}}$ & $0.647^{\mathrm{b}}$ & $0.558^{\mathrm{d}}$ \\
\hline $150 \times \mathrm{RD}$ & $0.618^{\mathrm{b}}$ & $0.656^{\mathrm{ab}}$ & $0.523^{\mathrm{d}}$ & $0.630^{\mathrm{d}}$ & $0.764^{\mathrm{ab}}$ & $0.632^{\mathrm{d}}$ & $0.556^{\mathrm{d}}$ & $0.646^{\mathrm{b}}$ & $0.545^{\mathrm{d}}$ \\
\hline \multirow[t]{2}{*}{$300 \times \mathrm{RD}$} & $0.607^{\mathrm{bc}}$ & $0.618^{\mathrm{b}}$ & $0.529^{\mathrm{d}}$ & $0.621^{\mathrm{d}}$ & $0.553^{\mathrm{d}}$ & $0.614^{\mathrm{d}}$ & $0.559^{\mathrm{d}}$ & $0.615^{\mathrm{b}}$ & $0.521^{\mathrm{d}}$ \\
\hline & 0.629 & 0.671 & 0.533 & 0.667 & 0.758 & 0.644 & 0.598 & 0.683 & 0.576 \\
\hline$* r$ & $-0.670 *$ & $-0.879 *$ & -0.110 & $-0.815^{*}$ & $-0.960 *$ & $-0.904 *$ & $-0.890 *$ & $-0.584 *$ & $-0.841^{*}$ \\
\hline
\end{tabular}

$\overline{{ }^{a-d} \text { Homogeneous groups in columns are marked with the same letter within a given microbial group (two-way ANOVA with Tukey's range test at }}$ a significance level of $p=0.01$. The between-subjects factor was fungicide dose, and the repeated measures factor was soil incubation time)

$S$ spiroxamine, $T e$ tebuconazole, $T r$ triadimenol; dose of fungicide: control (soil without fungicide), $R D$ dose recommended by the manufacturer, $30 \times R D 30$-fold higher than the recommended dose, $150 \times R D 150$-fold higher than the recommended dose, $300 \times R D 300$-fold higher than the recommended dose, average

* $r$ correlation coefficient significant at $p=0.01, n=3$

transformations (Kucharski and Wyszkowska 2008; Vig et al. 2008). Microbial degradation of crop protection products is a key mechanism that limits the accumulation of those toxic compounds in the soil environment. Those products are most rapidly broken down by microbial consortia capable of decomposing pesticides into non-toxic compounds. The remaining metabolic products can be used by microorganisms as a source of food for growth and development (Das and Dey 2013; Chennappa et al. 2014). The most pesticide-resistant microorganisms can be isolated from soil and used in the bioremediation of contaminated soil by bioaugmentation (Chen et al. 2011). According to the literature (Ahemad and Khan 2011; Clinton et al. 2011; Zhang et al. 2012; Rodrigues et al. 2013), soil pesticides are most effectively decomposed by microorganisms of the genera Arthrobacter, Pseudomonas, Bacillus, Rhodococcus, Mycoplana, Agrobacterium, Corynebacterium, Flavobacterium, Nocardia, Streptomyces, Penicillium, Aspergillus, Fusarium and Trichoderma. In this study, soil samples exposed to the mixture of spiroxamine, tebuconazole and triadimenol were colonized mainly by bacteria of the genus Bacillus and fungi of the genera Penicillium and Rhizopus. 
The dendrogram depicting the genetic relationships among bacterial strains isolated from soil, based on the nucleotide sequence of the 16S rRNA gene, contains two main groups (Fig. 1). The first group comprises soil bacteria with high genetic homology, including: Bacillus sp. JN872500.1, Bacillus anthracis KF475884.1, Bacillus cereus KF010349.1 and Bacillaceae bacterium DQ490406.1. The second group is composed of soil bacteria exposed to spiroxamine, tebuconazole and triadimenol in doses of RD and $300 \times \mathrm{RD}$. Those bacterial strains were identified in $100 \%$ as Bacillus sp. LM655314.1, Bacillus sp. KM083527.1, Bacillus aryabhattai LK391513.1, Bacillus megaterium KJ919967.1 and Bacillus megaterium KJ843149.1. The presence of the above bacteria in soil contaminated with a mixture of spiroxamine, tebuconazole and triadimenol could indicate that those microorganisms are capable of degrading the tested fungicide. This observation was confirmed by Cycoń et al. (2011) who isolated bacteria of the genus Bacillus from soil contaminated with thiophanate-methyl. They also identified bacteria of the genus Enterobacter which could have the ability to break down toxic compounds. In a study by Zhang et al. (2012), the Bacillus subtilis B19 strain was highly sensitive to the herbicide atrazine. The cited authors demonstrated that atrazine is decomposed by Rhodobacter sphaeroides W16 and Acinetobacter lwoffii DNS32.

Fungi are also capable of breaking down pesticides, and they play an important role in the decomposition process. Fungi produce enzymes which are more effective in degrading pesticides than bacterial enzymes (Przybulewska and Sienicka 2008). The phylogenetic tree of soil enzymes, developed based on nucleotide sequences in the ITS region, is presented in Fig. 2. The three microbial groups isolated from soil are presented in the dendrogram. The first group includes fungi isolated from the control sample: Penicillium sp. GU973745.1, Trichoderma viride GU048860.1, Acremonium cellulolyticus KF811039.1 and Talaromyces pinophilus KF751644.1. The second group contains Penicillium sp. KM249070.1 and Penicillium cyclopium KJ832691.1. The third group is composed of fungi of the genus Rhizo$p u s$. The genetic distance between those strains ranged from 0.001 to $0.008 \%$. Eman et al. (2013) isolated fungi of the genera Aspergillus, Penicillium, Fusarium, Alternaria, Bipolaris, Rhizopus, Trichoderma and Rhizoctonia from soil contaminated with glyphosate. Baćmaga et al. (2015b) isolated fungal strains Aphanoascus terreus AB861677.1 and Aphanoascus fulvescens JN943451.1 from soil samples exposed to azoxystrobin.

\section{Soil enzymes}

Uncontrolled contamination with pesticides can exert a significant influence on enzyme activity, one of the most important indicators of soil biochemical quality (Kucharski et al. 2009; Tao and Yang 2011; Baćmaga et al. 2014). Enzymes that participate in the biogeochemical cycle, transformations of organic matter and xenobiotics play a crucial role in the environment (Truu et al. 2008). Those enzymes include dehydrogenases, urease, phosphatases (Tejada 2009) and catalase (Bello et al. 2013).
Fig. 1 Phylogenetic tree of bacteria isolated from soil contaminated with the Falcon $460 \mathrm{EC}$ fungicide based on an analysis of the 16S rRNA gene. $C$ control soil without fungicide, $R D$ recommended by the manufacturer; $300 \times R D 300$ fold higher than the recommended dose

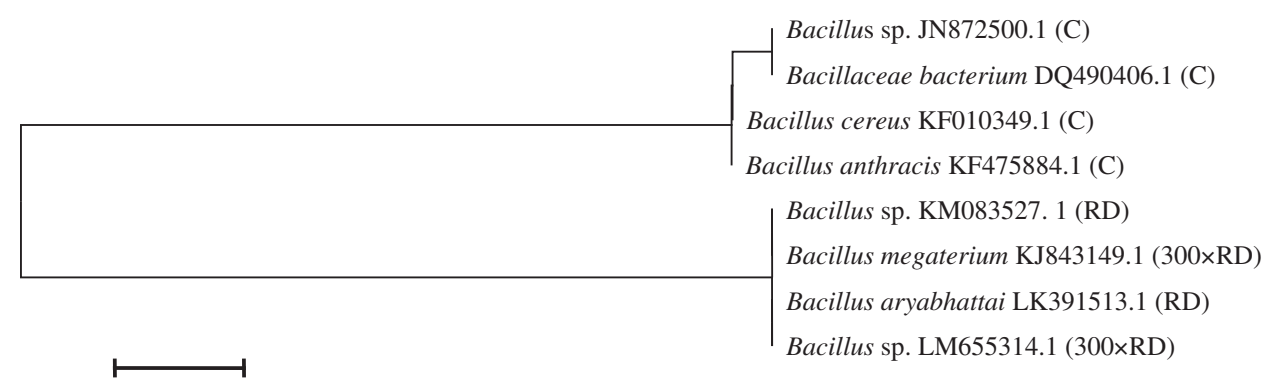

0.005

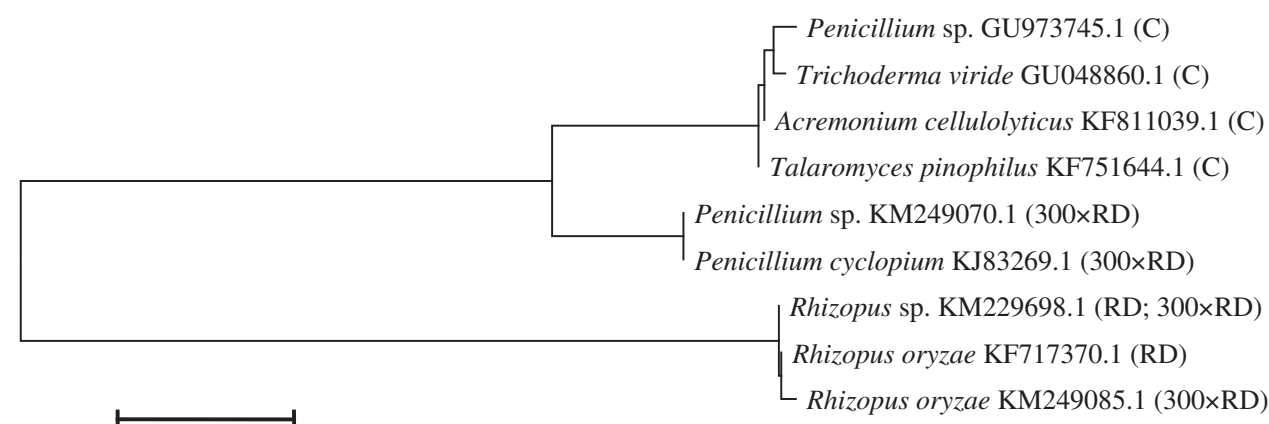

Fig. 2 Phylogenetic tree of fungi isolated from soil contaminated with the Falcon 460 fungicide based on an analysis of the ITS region. $C$ control soil without fungicide, $R D$ recommended by the manufacturer, $300 \times R D 300$ fold higher than the recommended dose 
Soil enzymatic activity is an indicator of the activity of enzymes in live cells as well as the concentrations of soil colloids and humic substances. The impact of pesticides on soil enzymes has not been fully elucidated due to the different fate of pesticides in the soil environment. For this reason, researchers place special emphasis on the influence exerted by the above chemical substances on the activity of soil enzymes (Mayanglambam et al. 2005). In the present study, the activity of soil enzymes was affected by both the dose of Falcon $460 \mathrm{EC}$ and the time of soil incubation. The latter factor exerted a greater effect, as the percentage of observed variance ranged from 21.48 to $98.43 \%$ (Table 1). Falcon 460 EC (a mixture of spiroxamine, tebuconazole and triadimenol) had a significant influence on soil enzymatic activity (Table 2). Soil incubation time and the interaction between both factors were statistically highly significant, as shown in Fig. 3 where enzyme vectors in the space of two first principal components were mapped based on the values standardized in PCA. The first two principal components explained $78.34 \%$ of total variance. The horizontal axis explained $58.11 \%$ and the vertical axis- $20.23 \%$ of total variance. The vectors representing the primary enzyme variables, such as urease, catalase and alkaline phosphatase, formed a homogeneous group, whereas vectors representing the activity of dehydrogenases and acid phosphatase formed the second group. The distribution of cases indicates that

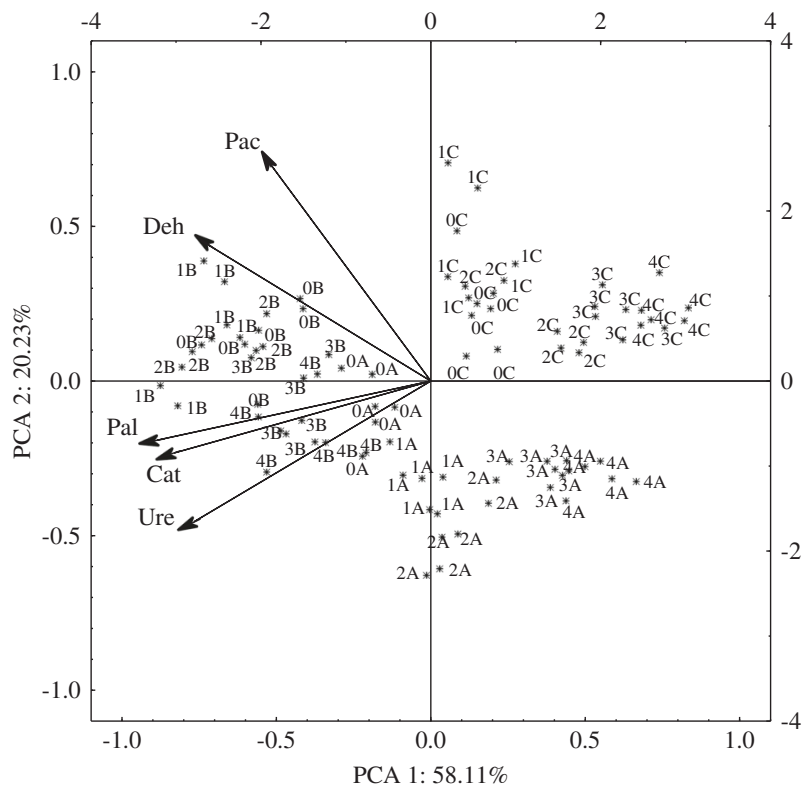

Fig. 3 Activity of soil enzymes exposed to the Falcon 460 EC fungicide based on PCA results. Deh dehydrogenases, Cat catalase, Ure urease, $\mathrm{Pac}$ acid phosphatase, $\mathrm{Pal}$ alkaline phosphatase; dose of active substances in $1 \mathrm{~kg}$ soil DM: 0-control (soil without fungicide), $1-\mathrm{RD}$ (dose recommended by the manufacturer), $2-30 \times \mathrm{RD}$ (30-fold higher than the recommended dose), 3-150 $\times$ RD (150-fold higher than the recommended dose), 4-300 $\times \mathrm{RD}$ (300-fold higher than the recommended dose); soil incubation time: A-30 days, B60 days, $\mathrm{C}-90$ days enzyme activity was determined by fungicide dose and soil incubation time. The dose recommended by the manufacturer generally stimulated enzyme activity. Higher fungicide doses inhibited enzyme activity, and the highest dose of $300 \times$ RD exerted the most inhibitory effect. When applied at the highest dose, the Falcon 460 EC fungicide induced the greatest changes in enzyme activity on experimental day 90. Similar results were reported by Baćmaga et al. (2015b) in whose study, azoxystrobin inhibited the activity od dehydrogenases, catalase, urease, acid phosphatase and alkaline phosphatase. In the work of Chen et al. (2001), benomyl and captan exerted the most inhibitory effect on dehydrogenases and acid phosphatase. Jastrzębska and Kucharski (2007) demonstrated that cyprodinil and a mixture of dimoxystrobin and econazole decreased the activity of dehydrogenases and urease. The inhibitory effect of fungicides on soil enzymes was also reported by Walia et al. (2014), in whose study, mancozeb doses of 10 to $2000 \mathrm{mg}$ $\mathrm{kg}^{-1}$ inhibited the activity of phosphatases, amylase and invertase. Kucharski et al. (2016) tested the Boreal 58 WG herbicide (active ingredients flufenacet and isoxaflutole) and reported that overexposure to this product decreased the activity of dehydrogenases, catalase, urease, arylsulfatase and $\beta$-glucosidase. There is also evidence to suggest that pesticides are capable of stimulating soil enzymes. Singh and Kumar (2008) demonstrated that acetamipirid enhanced the activity of dehydrogenases, whereas the stimulatory effect of carfentrazone-ethyl on acid phosphatase and alkaline phosphatase was reported by Baćmaga et al. (2012). The stimulatory effect of those pesticides could be attributed to the adaptive capabilities of soil microorganisms which minimize the negative influence of chemical stressors under adverse conditions. Those enzymes could also be protected by clay fractions or humic substances present in soil. The protective effect of those substances could have reduced enzyme sensitivity to pesticides.

The influence of pesticides on soil resistance, determined based on enzyme activity levels, has not been widely explored in the literature. The resistance of soil (RS) is defined as the stability of a soil ecosystem under exposure to stress (Orwin and Wardle 2004; Griffiths and Philippot 2013). Soil resistance values range from -1 to 1 . Values closer to 1 represent soils more resistant to stress factors, whereas values closer to -1 point to a greater influence of stressors (Orwin and Wardle 2004). Excessive doses of the tested fungicide decreased the RS values of enzymes, excluding dehydrogenases (Table 5). Dehydrogenase activity was not significantly influenced by a mixture of spiroxamine, tebuconazole and triadimenol, and its RS values were determined in the range of 0.852 (RD) to 0.902 $(150 \times \mathrm{RD})$. The most extensive changes were noted in response to the fungicide dose of $300 \times \mathrm{RD}$ which lowered the RS values of catalase by $10.46 \%$, urease-by $36.92 \%$, 
Table 5 Resistance (RS) index of enzymes in soil contaminated with the Falcon 460 EC fungicide on day 30

\begin{tabular}{llllll}
\hline Dose S + Te + Tr & Deh & Cat & Ure & Pac & Pal \\
\hline RD & $0.852^{\mathrm{a}}$ & $0.882^{\mathrm{a}}$ & $0.921^{\mathrm{a}}$ & $0.790^{\mathrm{a}}$ & $0.852^{\mathrm{a}}$ \\
$30 \times \mathrm{RD}$ & $0.898^{\mathrm{a}}$ & $0.790^{\mathrm{ab}}$ & $0.961^{\mathrm{a}}$ & $0.717^{\mathrm{ab}}$ & $0.821^{\mathrm{a}}$ \\
$150 \times \mathrm{xRD}$ & $0.902^{\mathrm{a}}$ & $0.817^{\mathrm{ab}}$ & $0.599^{\mathrm{b}}$ & $0.699^{\mathrm{ab}}$ & $0.761^{\mathrm{ab}}$ \\
$300 \times \mathrm{RD}$ & $0.866^{\mathrm{a}}$ & $0.736^{\mathrm{b}}$ & $0.581^{\mathrm{b}}$ & $0.659^{\mathrm{b}}$ & $0.684^{\mathrm{b}}$ \\
& 0.880 & 0.806 & 0.766 & 0.716 & 0.780 \\
$* r$ & -0.015 & $-0.802^{*}$ & $-0.895^{*}$ & $-0.879^{*}$ & $-0.996^{*}$ \\
\hline
\end{tabular}

${ }^{a-b}$ Homogeneous groups in columns are marked with the same letter within a given enzyme group (one-way ANOVA with Tukey's range test at a significance level of $p=0.01$ )

Deh dehydrogenases, Cat catalase, Ure urease, Pac acid phosphatase, $\mathrm{Pal}$ alkaline phosphatase, $S$ spiroxamine, Te tebuconazole, $\mathrm{Tr}$ triadimenol; dose of fungicide: RD (dose recommended by the manufacturer), $30 \times R D 30$-fold higher than the recommended dose, $150 \times R D 150$-fold higher than the recommended dose, $300 \times R D 300$ fold higher than the recommended dose, average

* $r$ correlation coefficient significant at $p=0.01, n=3$

acid phosphatase-by $16.58 \%$ and alkaline phosphataseby $19.72 \%$. Based on the average RS values, the analyzed enzymes were arranged in the following order (from most to least resistant): dehydrogenases $(0.880)>$ catalase $(0.806)>$ alkaline phosphatase $(0.780)>$ urease $(0.766)>$ acid phosphatase (0.716). Similar results were reported by Tomkiel et al. (2015) in whose study, acid phosphatase was most sensitive and dehydrogenases were most resistant to carfentrazone-ethyl. Baćmaga et al. (2015b) demonstrated that urease was most sensitive to overexposure of azoxystrobin, whereas dehydrogenases, similarly to this study, were most resistant to the tested fungicide. Tomkiel et al. (2014) also reported that urease was most sensitive to a pesticide containing two active ingredients-pethoxamid and terbuthylazine.

\section{Fungicide phytotoxicity}

Detailed knowledge about the toxic effects of fungicides is required to reliably evaluate the associated environmental risks. The main tool in the analytical process are ecotoxicological tests kits suitable for organisms representing various trophic levels (Joly et al. 2015). Plants play a very important role in soil ecosystems, which is why phytotoxicity tests are increasingly often used. Despite the above, the influence of pesticides on the growth and development of plants has not been thoroughly investigated to date (Bettiol et al. 2015). The effect of the Falcon 460 EC fungicide on the growth of Lepidium sativum, Sinapis alba and Sorghum saccharatum was determined by the dose and persistence in soil (Table 6). Seed germination was determined by fungicide dose in $41.99-50.65 \%$, and by soil incubation time in $25.96-47.05 \%$. Root elongation was
Table 6 The influence of the Falcon 460 EC fungicide on seed germination and root elongation in the Phytotoxkit test

\begin{tabular}{|c|c|c|c|c|c|c|}
\hline \multirow[t]{3}{*}{ Dose $\mathrm{S}+\mathrm{Te}+\mathrm{Tr}$} & \multicolumn{3}{|c|}{$\begin{array}{l}\text { Inhibition of seed } \\
\text { germination }(\%)\end{array}$} & \multicolumn{3}{|c|}{$\begin{array}{l}\text { Inhibition of root elongation } \\
(\%)\end{array}$} \\
\hline & \multicolumn{6}{|c|}{ Soil incubation time, days } \\
\hline & 30 & 60 & 90 & 30 & 60 & 90 \\
\hline \multicolumn{7}{|c|}{ Lepidium sativum } \\
\hline $\mathrm{RD}$ & $8.66^{\mathrm{a}}$ & $14.24^{\mathrm{b}}$ & $23.97^{\mathrm{c}}$ & $11.04^{\mathrm{d}}$ & $12.82^{\mathrm{d}}$ & $16.10^{\mathrm{e}}$ \\
\hline $30 \times \mathrm{RD}$ & $15.73^{\mathrm{b}}$ & $32.03^{\mathrm{f}}$ & $32.16^{\mathrm{f}}$ & $19.36^{\mathrm{a}}$ & $28.27^{\mathrm{c}}$ & $28.49^{\mathrm{c}}$ \\
\hline $150 \times x R D$ & $20.45^{\mathrm{c}}$ & $41.87^{\mathrm{g}}$ & $41.93^{\mathrm{b}}$ & $24.69^{\mathrm{b}}$ & $33.93^{\mathrm{f}}$ & $42.19^{\mathrm{g}}$ \\
\hline \multirow[t]{2}{*}{$300 \times \mathrm{RD}$} & $30.07^{f}$ & $43.35^{\mathrm{g}}$ & $43.76^{\mathrm{f}}$ & $34.26^{\mathrm{f}}$ & $34.34^{\mathrm{f}}$ & $43.03^{\mathrm{g}}$ \\
\hline & 18.73 & 32.87 & 35.46 & 22.34 & 27.34 & 32.45 \\
\hline$*_{r}$ & $0.971 *$ & $0.813 *$ & $0.893^{*}$ & $0.964 *$ & $0.755^{*}$ & $0.862 *$ \\
\hline \multicolumn{7}{|l|}{ Sinapsis alba } \\
\hline $\mathrm{RD}$ & $19.97^{\mathrm{h}}$ & $22.74^{\mathrm{d}}$ & $33.15^{\mathrm{a}}$ & $13.89^{\mathrm{i}}$ & $21.09^{\mathrm{d}}$ & $32.83^{\mathrm{a}}$ \\
\hline $30 \times \mathrm{RD}$ & $26.64^{\mathrm{e}}$ & $31.81^{\mathrm{a}}$ & $41.65^{\mathrm{c}}$ & $20.07^{\mathrm{h}}$ & $26.77^{\mathrm{e}}$ & $42.21^{\mathrm{b}}$ \\
\hline $150 \times x R D$ & $31.44^{\mathrm{a}}$ & $36.13^{\mathrm{b}}$ & $58.49^{\mathrm{f}}$ & $26.36^{\mathrm{e}}$ & $35.13^{\mathrm{a}}$ & $56.19^{\mathrm{f}}$ \\
\hline \multirow[t]{2}{*}{$300 \times \mathrm{RD}$} & $38.04^{\mathrm{b}}$ & $39.78^{b}$ & $71.82^{\mathrm{g}}$ & $27.44^{\mathrm{e}}$ & $47.20^{\mathrm{c}}$ & $71.32^{\mathrm{g}}$ \\
\hline & 29.02 & 32.62 & 51.28 & 21.94 & 32.55 & 50.64 \\
\hline$* r$ & $0.959 *$ & $0.881 *$ & $0.984^{*}$ & $0.878 *$ & $0.993 *$ & $0.987 *$ \\
\hline \multicolumn{7}{|c|}{ Sorghum saccharatum } \\
\hline $\mathrm{RD}$ & $15.68^{\mathrm{a}}$ & $24.82^{\mathrm{b}}$ & $25.52^{\mathrm{b}}$ & $18.98^{\mathrm{a}}$ & $23.80^{\mathrm{b}}$ & $33.49^{\mathrm{f}}$ \\
\hline $30 \times \mathrm{RD}$ & $24.28^{\mathrm{b}}$ & $33.32^{\mathrm{c}}$ & $31.35^{\mathrm{c}}$ & $24.88^{\mathrm{b}}$ & $27.49^{\mathrm{c}}$ & $35.87^{\mathrm{f}}$ \\
\hline $150 \times x R D$ & $30.94^{\mathrm{c}}$ & $40.29^{\mathrm{f}}$ & $46.14^{\mathrm{g}}$ & $22.68^{\mathrm{b}}$ & $29.33^{\mathrm{c}}$ & $47.23^{\mathrm{g}}$ \\
\hline \multirow[t]{2}{*}{$300 \times \mathrm{RD}$} & $30.63^{\mathrm{c}}$ & $42.55^{\mathrm{f}}$ & $47.74^{\mathrm{g}}$ & $30.94^{\mathrm{c}}$ & $36.15^{\mathrm{f}}$ & $49.66^{\mathrm{g}}$ \\
\hline & 25.38 & 35.24 & 37.69 & 24.37 & 29.19 & 41.56 \\
\hline$* r$ & $0.809 *$ & 0.884 & $0.912 *$ & $0.844 *$ & $0.971 *$ & $0.941^{*}$ \\
\hline
\end{tabular}

${ }^{a-g}$ Homogeneous groups in columns are marked with the same letter within a given plant species separately for inhibition of seed germination and root elongation (two-way ANOVA with Tukey's range test at a significance level of $p=0.01$. The between-subjects factor was fungicide dose, and the repeated measures factor was soil incubation time)

$S$ spiroxamine, $T e$ tebuconazole, $\operatorname{Tr}$ triadimenol; dose of fungicide: RD (dose recommended by the manufacturer), $30 \times R D 30$-fold higher than the recommended dose, $150 \times R D 150$-fold higher than the recommended dose, $300 \times R D 300$-fold higher than the recommended dose, average

* $r$ correlation coefficient significant at $p=0.01, n=3$

affected by fungicide dose in $24.62-66.17 \%$, and by soil incubation time in 13.39-52.35\% (Table 1). The results of repeated measures ANOVA presented in Table 2 point to highly significant effects of the between-subjects factor (fungicide dose) and the repeated measures factor (soil incubation time) on seed germination and root elongation. The fungicide dose $\times$ soil incubation time interaction also led to significant changes. The highest fungicide dose $(300 \times \mathrm{RD})$ strongly inhibited germination capacity and root elongation. The average germination capacity of Lepidium sativum seeds decreased by $29.02 \%$, Sinapis alba seedsby $49.88 \%$ and Sorghum saccharatum seeds-by $40.31 \%$ in response to the highest fungicide dose. Average root elongation was also reduced relative to control by $37.21 \%$ in Lepidium sativum, $48.65 \%$ in Sinapis alba and $38.92 \%$ in Sorghum saccharatum. The average seed germination 
and root elongation values were most inhibited on day 90 . The observed reduction in seed germination capacity on day 90 ranged from $35.46 \%$ (Lepidium sativum) to $51.28 \%$ (Sinapis alba), and the decrease in root elongation-from $32.45 \%$ (Lepidium sativum) to $50.64 \%$ (Sinapis alba). Sinapsis alba was most sensitive to the mixture of spiroxamine, tebuconazole and triadimenol which inhibited its seed germination capacity by $37.64 \%$ and root elongation by $35.04 \%$ on average. The adverse influence of pesticides on plant growth was also demonstrated by Bettiol et al. (2015) who evaluated the phytotoxicity of three herbicides (chloroxynil, bromoxynil and ioxynil) on seed germination and root elongation of Leptidium sativum. In the cited study, ioxynil exerted the most toxic effect on the analyzed plant. In a study by Wyszkowska (2002), the growth of spring rapeseed and white mustard was most significantly inhibited by the Treflan 480 EC herbicide containing triflurarin. The inhibitory effects of pesticides on plants were also reported by Kucharski and Wyszkowska (2008) in a study of the Apyros 74 WG herbicide.

\section{Conclusions}

Fungicides can exert toxic effects on both target and nontarget species. Those chemical compounds reach the soil ecosystem and pose a threat for living organisms, in particular soil-dwelling microbes and plants. This study analyzed the influence of the Falcon 460 EC fungicide, containing active ingredients spiroxamine, tebuconazole and triadimenol, on soil-dwelling microbes, soil enzymes and plants. Exposure to the tested fungicide led to changes in the values of the colony development index and the eco-physiological diversity index of organotrophic bacteria, actinomycetes and fungi. Control soil was colonized mainly by bacteria of the genus Bacillus and fungi of the genera Penicillium, Trichoderma, Acremonium and Talaromyces, whereas the predominant microorganisms in experimental soil contaminated with the Falcon 460 EC fungicide were bacteria of the genus Bacillus and fungi of the genera Penicillium and Rhizopus. The tested fungicide also strongly inhibited the activity of dehydrogenases, catalase, urease, acid phosphatase and alkaline phosphatase. Acid phosphatase was most sensitive to the evaluated product. The fungicide also exerted a toxic effect on the seed germination capacity and root elongation of Lepidium sativum, Sinapsis alba and Sorgo saccharatum. Falcon 460 EC had the most inhibitory influence on Sinapsis alba. Microbiological and biochemical parameters are used to evaluate the toxic impact of fungicides on the soil environment. The results of this study indicate that overexposure to the tested active ingredients (in doses of $30 \times \mathrm{RD}$ to
$300 \times \mathrm{RD}) \quad$ can pose a threat for soil-dwelling microorganisms.

Acknowledgments The study was financed by a grant from the Ministry of Science and Higher Education for statutory activities.

\section{Compliance with ethical standards}

Conflict of interest The authors declare that they have no conflict of interests.

\section{References}

Ahemad M, Khan MS (2011) Effect of tebuconazole-tolerant and plant growth promoting Rhizobium isolate MRP1 on pea-Rhizobium symbiosis. Sci Hortic 129:266-272

Alef K, Nannipieri P (1998) Methods in applied soil microbiology and biochemistry. In: Alef K, Nannipieri P (ed), Academic Press, Harcourt Brace \& Company, London, pp 316-365

Alef K, Nannipieri P, Trazar-Capeda C (1998) Phosphatase activity in: methods in applied soil microbiology and biochemistry. In: Alef K, Nannipieri P (ed), Academic Press Harcourt Brace \& Company, London, pp 335-344

Alexander M (1973) Microorganisms and chemical pollution. Bioscience 23:509-515

Arias-Estéves M, López-Periago E, Martinez-Carbaloo E, SimalGándara J, Garciario L (2008) The mobility and degradation of pesticides in soils and the pollution of groundwater resources. Agric Ecosyst Environ 123:247-260

Baćmaga M, Boros E, Kucharski J, Wyszkowska J (2012) Enzymatic activity in soil contaminated with the Aurora 40 WG herbicide. Environ Prot Eng 38(1):91-102

Baćmaga M, Borowik A, Kucharski J, Tomkiel M, Wyszkowska J (2015a) Microbial and enzymatic activity of soil contaminated with a mixture of diflufenican + mesosulfuron-methyl + iodosulfuron-methyl-sodium. Environ Sci Pollut Res 22:643-656

Baćmaga M, Kucharski J, Wyszkowska J (2015b) Microbial and enzymatic activity of soil contaminated with azoxystrobin. Environ Monit Assess 187:615

Baćmaga M, Kucharski J, Wyszkowska J, Borowik A, Tomkiel M (2014) Responses of microorganisms and enzymes to soil contamination with metazachlor. Environ Earth Sci 72:22512262

Baćmaga M, Kucharski J, Wyszkowska J, Tomkiel M, Borowik A (2015c) Response of actinomycetes, phosphatases and urease to soil contamination with herbicides. Ecol Chem Eng S 22(2):255

Banks KE, Hunter DH, Wachal DJ (2005) Chlorpyrifos in surface waters before and after a federally mandated ban. Environ Int 31:351-356

Bello D, Trasar-Cepeda C, Leirós MC, Gil-Sotres F (2013) Modification of enzymatic activity in soils of contrasting $\mathrm{pH}$ contaminated with 2,4-dichlorophenol and 2,4,5-trichlorophenol. Soil Biol Biochem 56:80-86

Bettiol C, De Vettori S, Minervini G, Zuccon E, Marchetto D, Ghirardini AV, Argese E (2015) Assessment of phenolic herbicide toxicity and mode of action by different assays. Environ Sci Pollut Res 23:1-11

Carter MR (1993) Soil sampling and methods of analysis. Canadian Society of Soil Science. Lewis Publishers, London

Chatterjee NS, Gupta S, Varghese E (2013) Degradation of metaflumizone in soil: Impact of varying moisture, light, temperature, atmospheric $\mathrm{CO}_{2}$ level, soil type and soil sterilization. Chemosphere 90:729-736 
Chen S, Yang L, Hu M, Liu J (2011) Biodegradation of fenvalerate and 3-phenoxybenzoic acid by a novel Stenotrophomonas sp. strain ZS-S-01 and its use in bioremediation of contaminated soils. Appl Microbiol Biotechnol 90:755-767

Chen SK, Edwards CA, Subler S (2001) Effects of the fungicides benomyl, captan and chlorothalonil on soil microbial activity and nitrogen dynamics in laboratory incubations. Soil Biol Biochem 33:1971-1980

Chennappa G, Adkar-Purushothama CR, Suraj U, Tamilvendan K, Sreenivasa MY (2014) Pesticide tolerant Azotobacter isolated from paddy growing areas of northern Karnataka, India. World J Microb Biotechnol 30(1):1-17

Clinton B, Warden AC, Haboury S, Easton CJ, Kotsonis S, Taylor MC, Oakeshott JG, Russell C, Scott RJ (2011) Bacterial degradation of strobilurin fungicides: a role for a promiscuous methyl esterase activity of the subtilisin proteases? Biocatal Biotransform 29(4):1-11

Cycoń M, Wójcik M, Piotrowska-Seget Z (2011) Biodegradation kinetics of the benzimidazole fungicide thiophanate-methyl by bacteria isolated from loamy sand soil. Biodegradation 22:573583

Das AC, Dey S (2013) Effect of systemic herbicides on microbial biomass in relation to availability of some plant nutrients in an alluvial soil of West Bengal. Bull Environ Contam Toxicol 90:666-672

De Leij FAAM, Whipps JM, Lynch JM (1993) The use of colony development for the characterization of bacterial communities in soil and on roots. Microb Ecol 27:81-97

Demenaou J, Monkiedje A, Nin T, Foto SM, Nola M, Kemka N (2004) Changes in soil Chemical properties and microbial activity response to the fungicide Rridomil Gold Plus Copper. Int J Environ Res Public Health 1:26-34

Dong F, Liu X, Zheng Y, Cao Q, Li C (2010) Stereoselective degradation of fungicide triadimenol in cucumber plants. Chirality 22:292-298

Eman A, Abdel-Megeed A, Suliman AA, Sadik MW, Sholkamy EN (2013) Biodegradation of glyphosate by fungal strains isolated from herbicides polluted-soils in Riyadh area. Int J Curr Microbiol Appl Sci 2(8):359-381

Garrison AW, Avants JK, Jones WJ (2011) Microbial transformation of triadimefon to triadimenol in soils: selective production rates of triadimenol stereoisomers affect exposure and risk. Environ Sci Technol 45:2186-2193

Griffiths BS, Philippot L (2013) Insights into the resistance and resilience of the soil microbial community. FEMS Microbiol Rev $37: 112-129$

Guo P, Zhu L, Wang J, Wang J, Xie H, Lv D (2015) Enzymatic activities and microbial biomass in black soil as affected by azoxystrobin. Environ Earth Sci 74:1353-1361

Harris DC (2006) Quantitative chemical analysis. Michelson Laboratory Chine Lake USA. WH Freeman and Company 7th edn. p 1008.

Jastrzębska E, Kucharski J (2007) Dehydrogenases, urease and phosphatases activities of soil contaminated with fungicides. Plant Soil Environ 53(2):51-57

Jezierska-Tys S, Rutkowska A (2013) Soil response to chemicals used in a field experiment. Int Agrophys 27(2):151-158

Joly P, Bonnemoy F, Besse-Hoggan P, Perrière F, Crouzet O, Cheviron N, Mallet C (2015) Responses of limagne "clay/organic matter-rich" soil microbial communities to realistic formulated herbicide mixtures, including s-metolachlor, mesotrione, and nicosulfuron. Water Air Soil Pollut 226:413

Katayama A, Bhula R, Burns GR, Carazo E, Felsot A, Hamilton D, Harris C, Kim YH, Kleter G, Koedel W, Linders J, Peijnenburg JGMW, Sabljic A, Stephenson RG, Racke DK, Rubin B, Tanaka K, Unsworth J, Wauchope RD (2010) Bioavailability of xenobiotics in the soil environment. Rev Environ Contam Toxicol 203:1-86

Komárek M, Cadkova E, Chrastny V, Bordas F, Bollinger JC (2010) Contamination of vineyard soils with fungicides: a review of environmental and toxicological aspects. Environ Int 36: $138-151$

Kucharski J, Baćmaga M, Wyszkowska J (2009) Effect of herbicydes on the course of ammonification in soil. $\mathrm{J}$ Elementol 14(3):477-487

Kucharski J, Wyszkowska J (2008) Biological properties of soil contaminated with the herbicide Apyros 75 WG. J Elementol 13(3):357-371

Kucharski J, Tomkiel M, Baćmaga M, Borowik A, Wyszkowska J (2016) Enzyme activity and microorganisms diversity in soil contaminated with the Boreal 58 WG herbicide. J Environ Sci Health B 51(7):446-454

Lipińska A, Wyszkowska J, Kucharski J (2015) Microbiological diversity and biochemical activity of soil contaminated with PAHs. Environ Sci Pollut Res 22(23):18519-18530

Maltby L, Brock TCM, Van den Brink PJ (2009) Fungicide risk assessment for aquatic ecosystems: importance of interspecific variation, toxic mode of action, and exposure regime. Environ Sci Technol 43:7556-7563

Martin J (1950) Use of acid rose bengal and streptomycin in the plate method for estimating soil fungi. Soil Sci 69:215-233

Mayanglambam T, Vig K, Singh DK (2005) Quinalphos persistence and leaching under field conditions and effects of residues on dehydrogenase and alkaline phosphomonoesterases activities in soil. Bull Environ Contam Toxicol 75:1067-1076

Menon P, Gopal M, Parsad R (2005) Effects of chlorpyrifos and quinalphos on dehydrogenase activities and reduction of $\mathrm{Fe}^{3+}$ in the soils of two semi-arid fields of tropical India. Agric Ecosyst Environ 108:73-83

Muñoz-Leoz B, Ruiz-Romera E, Antigüedad I, Garbisu C (2011) Tebuconazole application decreases soil microbial biomass and activity. Soil Biol Biochem 43:2176-2183

Nelson DW, Sommers LE (1996) Total carbon, organic carbon, and organic matter in method of soil analysis: chemical methods. In: Sparks DL (ed) American Society of Agronomy, Madison, pp 1201-1229

Öhlinger R (1996) Dehydrogenase activity with the substrate TTC. In: Schinner F, Öhlinger R, Kandeler E, Margesin R (ed) Methods in Soil Biology. Berlin, Springer, Verlag, pp 241-243

Orwin KH, Wardle DA (2004) New indices for quantifying the resistance and resilience of soil biota to exogenous disturbance. Soil Biol Biochem 36:1907-1912

Parkinson D, Gray FRG, Williams ST (1971) Methods for studying the ecology of soil micro-organism. IBP Handbook 19. Blackwell Scientific Publication, Oxford

Przybulewska K, Sienicka K (2008) Decomposition of atrazine by microorganisms isolated from long-term herbicide experiment soil. Ecol Chem Eng S 15(4):479-487

Ratcliff AW, Busse MD, Shestak CJ (2006) Changes in microbial community structure following herbicide (glyphosate) addition to forest soils. Appl Soil Ecol 34:114-124

Rodrigues ET, Lopes I, Pardal MÂ (2013) Occurrence fate and effects of azoxystrobin in aquatic ecosystems: a review. Environ Int 53:18-28

Sarathchandra SU, Burch G, Cox NR (1997) Growth patterns of bacterial communites in the rhizoplane and rhizosphere of with clover (Trifolium repens L.) and perennial ryegrass (Lolium perenne L.) in long-term pasture. Appl Soil Ecol 6:293-299

Seiber JN, Kleinschmidt LA (2011) Contribution of pesticide residue chemistry to improving food and environmental safety: past and present accomplishments and future challenges. J Agric Food Chem 59:7536-7543 
Singh DK, Kumar S (2008) Nitrate reductase, arginine deaminase, urease and dehydrogenase activities in natural soil (ridges with forest) and in cotton soil after acetamipirid treatments. Chemosphere 71:412-418

Statsoft, Inc, Statistica (2015) Data Analysis Software System, version 12.5. http://www.statsoft.com

Sukul P, Zühlke S, Lamshöft M, Rosales-Conrado N, Spiteller M (2010) Dissipation and metabolism of (14)C-spiroxamine in soil under laboratory condition. Environ Pollut 158(5):1542-1550

Tao L, Yang H (2011) Fluroxypyr biodegradation in soils by multiple factors. Environ Monit Assess 175:227-238

Tejada M (2009) Evolution of soil biological properties after addition of glyphosate, diflufenican and glyphosate + diflufenican herbicides. Chemosphere 76:365-373

Tejada M, Benítez C, Gómez I, Parrado J (2011) Use of biostimulants on soil restoration: Effects on soil biochemical properties and microbial community. Appl Soil Ecol 49:11-17

Tomkiel M, Baćmaga M, Wyszkowska J, Kucharski J, Borowik A (2015) The effect of carfentrazone-ethyl on soil microorganisms and soil enzymes activity. Arch Environ Prot 41(3):3-10

Tomkiel M, Wyszkowska J, Kucharski J, Baćmaga M, Borowik A (2014) Response of microorganisms and enzymes to soil contamination with the herbicide successor T 550 SE. Environ Prot Eng 40(4):15-27

Truu M, Truu J, Ivask M (2008) Soil microbiological and biochemical properties for assessing the effect of agricultural management practices in Estonian cultivated soils. Eur J Soil Biol 44:231-237

Vig K, Singh DK, Agarwal HC, Dhawan AK, Dureje P (2008) Soil microorganisms in cotton fields sequentially treated with insecticides. Ecotoxicol Environ Saf 69:263-276

Walia A, Mehta P, Guleria S, Chauhan A, Shirkot CK (2014) Impact of fungicide mancozeb at different application rates on soil microbial populations, soil biological processes and enzyme activities in soil. Sci World J 1-9.

Wang MC, Gong M, Zang HB, Hua XM, Yao J, Pang YJ, Yang YH (2006) Effect of methamidophos and urea application on microbial communities in soils as determined by microbial biomass and community level physiological profiles. J Environ Sci Health B 41:399-413

Widenfalk A, Bertilsson S, Sundh I, Goedkoop W (2008) Effects of pesticides on community composition and activity of sediment microbes-responses at various levels of microbial community organization. Environ Pollut 152:576-584

Wightwick AM, Reichman SM, Menzies NW, Allinson G (2013) The effects of copper hydroxide, captan and trifloxystrobin fungicides on soil phosphomonoesterase and urease activity. Water Air Soil Pollut 224:1703

World Reference Base of Soil Resources (2014) A framework for international classification, correlation and communication. World Soils Resources Report. 103, FAO, Rome

Wyszkowska J (2002) Effect of soil contamination with Treflan 480 EC on biochemical properties of soil. Pol J Environ Stud 11 (1):71-77

Wyszkowska J, Kucharski J (2004) Biochemical and physicochemical properties of soil contaminated with herbicide Triflurotox 250 EC. Pol J Environ Stud 13(2):223-231

Zhang Q, Zhu L, Wang J, Xie H, Wang J, Wang F, Sun F (2014) Effects of fomesafen on soil enzyme activity, microbial population, and bacterial community composition. Environ Monit Assess 186(5):2801-2812

Zhang Y, Meng D, Wang Z, Guo H, Wang Y, Wang X, JDong $X$ (2012) Oxidative stress response in atrazine]degrading bacteria exposed to atrazine. J Hazard Mater 229230:434-438 